\title{
Falls in hospital settings: a longitudinal study
}

\author{
Cidalina Abreu ${ }^{1}$ \\ Aida Mendes ${ }^{2}$ \\ José Monteiro ${ }^{3}$ \\ Filipa Raquel Santos ${ }^{3}$
}

\begin{abstract}
This study aims to assess the prevalence of falls, understand their consequences, identify causes and analyze intervention strategies to prevent them. This is a descriptive longitudinal study, from 2007 to 2009, in which nurses recorded patients' falls in a medicine ward, using a scale developed for this end. Most falls occurred with partially dependent patients, with a mean age ranging from 64 to 74 years. The bedroom was, in all of these years, the place where most of these falls occurred. Although most falls did not have consequences, they were observed in $36 \%$ of the cases. The number of falls increased throughout the years of the study. There was also a difference in the percentage of occurrences in the afternoon and night shifts (39\% in 2007, $57 \%$ in 2008 and $64 \%$ in 2009). The identification of obstacles to referral and how to overcome them are analyzed here.
\end{abstract}

Descriptors: Accidental Falls; Aged; Accident Prevention; Safety.

\footnotetext{
${ }^{1}$ MSc, Adjunct Professor, Escola Superior de Enfermagem de Coimbra, Portugal.

${ }^{2}$ PhD, Coordinating Professor, Escola Superior de Enfermagem de Coimbra, Portugal.

${ }^{3}$ RN, Hospitais da Universidade de Coimbra, Portugal.
} 


\section{Quedas em meio hospitalar: um estudo longitudinal}

Este estudo visou avaliar a prevalência das quedas, conhecer as suas consequências, identificar as causas e estudar estratégias de intervenção para preveni-las. É um estudo descritivo longitudinal, de 2007 a 2009, com registro, pelos enfermeiros, das quedas dos doentes, num serviço de medicina, em escala construída para o efeito. A maioria das quedas ocorreu em doentes parcialmente dependentes, variando a idade entre 64 e 74 anos. O quarto foi, em todos os anos, o local onde maioritariamente ocorreram. Embora da maioria das quedas não houvesse resultado consequências, essas foram registradas em $36 \%$ dos casos. O número de quedas registrado aumentou ao longo dos anos do estudo. De igual modo se revelou diferença na proporcionalidade do número de registros para os turnos da tarde e noite (39\% em 2007, 57\% em 2008 e $64 \%$ em 2009). A identificação de barreiras à referenciação e como as ultrapassar são analisadas.

Descritores: Acidentes por Quedas; Idoso; Prevenção de Acidentes; Segurança.

\section{Caídas en el medio hospitalario: un estudio longitudinal}

Este estudio intenta evaluar la prevalencia de las caídas, conocer sus consecuencias, identificar causas y estudiar estrategias de intervención para prevenirlas. Es un estudio descriptivo longitudinal, realizado entre 2007 y 2009, donde los enfermeros registraron las caídas de enfermos en un servicio de medicina, de acuerdo con una escala elaborada para este propósito. La mayoría de las caídas ocurrió en enfermos parcialmente dependientes, cuyas edades variaban entre 64 y 74 años. La habitación fue, en todos los años, donde mayoritariamente estas ocurrieron. Aunque la mayoría de las caídas no hayan tenido consecuencias, se registraron en $36 \%$ de los casos. Este número aumentó a lo largo de los años del estudio. Se rebeló, igualmente, una diferencia en la proporcionalidad del número de registros para los turnos de la tarde/ noche (39\%, 2007, 57\%, 2008 y 64\%, 2009). Se analiza la identificación de las barreras a la referencia y como rebasar estas barreras.

Descriptores: Caídas; Adultos Mayores; Prevención de Accidentes; Seguridad.

\section{Introduction}

The safety of patients hospitalized in health services is one of the priority concerns in quality control systems. The falls suffered by the patients during their hospitalization are one of the most important occurrences in the breakdown of security and are often responsible for an increased number of hospital days and worse recovery conditions. Hence, this has been a topic of research, studies and interventions at health institutions.

The World Health Organization (WHO) defines fall as an event which results in a person coming to rest inadvertently on the ground, with the inability to correct in due time and is determined by circumstances involving multiple factors that affect stability ${ }^{(1-2)}$. It is estimated that, in 2002, around the world, 391,000 people died due to this phenomenon. According to the same organization, these figures turn falls into the second main cause of death by involuntary accidents, immediately following on traffic accidents ${ }^{(1)}$.

These accidents are characteristic of extreme ages (under 5 and above 65 years of age). Falls are commonly considered a "geriatric syndrome", given its higher incidence in the elderly group. They represent the most frequent motive for visits to the emergency unit and the main cause of accidental death among aged people(3). 
According to the Inspecção-Geral das Actividades em Saúde (IGAS), in the Portuguese National Health Service, 4,200 accidents were registered in 2006, 2007 and January 2008 (a total of 25 months), related to patients' falls from stretchers or beds. In this study, it was ascertained that, in 85 of these cases, the patients ended up dying. The IGAS indicates that these falls took place in bathrooms, armchairs, wheelchairs and on slippery floors. IGAS found that, in January 2008, 13\% of the stretchers at 65 National Health Systems units (415) possessed no side rails, nor did 8,200 beds. This corresponds to $33 \%$ of all beds at the hospitals studied. In the same report, it is acknowledged though that the hospitals have made efforts to increase the number of protection structures $^{(4)}$. Due to this situation, we consider that this represents a severe public health problem, which affects these patients' increased discomfort and risk and entails possible implications for the hospitalization time, with a consequent increase in hospital costs, human and material resources ${ }^{(3)}$.

More than $70 \%$ of the falls happen in the rooms, when patients move to the bed, armchair or wheelchair, and $19 \%$ when walking from the bed to the bathroom and vice-versa(5). About $23 \%$ of the falls that affected hospitalized patients resulted in injuries, mainly bruises, sprains and lacerations (83\%), while $9 \%$ were fractures.

Falls in the hospital context are a result of different factors. The difference between the hospital and domestic environments, with their own movements and spatial and organizational alterations, can represent a big change, mainly for patients who are elderly or face more difficulties to adjust to changes in their environment. On the other hand, the alterations in the physical conditions of hospitalized people, whether associated or not with the disease that motivated this hospitalization, put them in a more fragile situation, frequently affecting their physical and psychological functioning.

Risk factors can be divided in two main groups, which are considered important to identify causes of falls: intrinsic and extrinsic. Intrinsic factors are considered directly related to the patient's physical and psychological situation, like the increased reaction time to the dangerous situation, musculoskeletal disorders, drugs like anxiolytics, among others. Extrinsic factors are considered as all factors direct or indirectly related with the context the patient is in, like inadequate lighting, presence of obstacles, absence of handrails and bathrooms and others ${ }^{(2-3,6)}$.
In recent years, nurses have globally been more attentive to patient falls. Nevertheless, it remains a reality that has been insufficiently documented and studied. On the other hand, the introduction of preventive measures to enhance patient safety not only needs better knowledge on this phenomenon, in each particular context, but also the mobilization of all stakeholders for the development of a culture of care quality.

The aim of this study was to assess the prevalence of falls, identify their causes, get to know their consequences and study intervention strategies for risk prevention and reduction.

\section{Methods}

A quantitative, descriptive and longitudinal epidemiological study was developed in 2007, 2008 and 2009, using database records on fall events and their characteristics.

The research was developed at a medical unit of a Portuguese university hospital. This type of service receives mainly elderly people from all over the country, but predominantly from the central region, with high levels of dependence for all forms of selfcare. Thirty-three beds are offered, divided in different rooms, within a large physical area. The most common diagnoses are pneumonias, respiratory and urinary infections and liver cirrhosis.

Movement levels during the morning shift are high, which is when the most significant part of care is delivered and more professionals are present from the entire multidisciplinary team. It is also during this period that many medical and nursing students are present, considering that, at a teaching hospital, this is an excellent unit for their learning, due to the multiple and frequent procedures, as well as the range of clinical situations and health care.

Three nurses and one operational assistant guarantee care during afternoon shifts (16-24h) and two nurses and one operational assistant during night shifts (24-8h).

During the study years, 1006, 874 and 922 patients were hospitalized at the unit, respectively. The research project, including the questionnaire for data recording, was presented to the nursing team, underlining the multifactorial nature of these events and the importance of knowledge about the falls phenomenon in hospital environments to improve care quality.

As there was no specific support to register this type of events at the unit, a questionnaire entitled "Falls in hospital settings" was used for data collections, 
which the researchers elaborated for all team nurses to use whenever this type of events took place. This questionnaire consists of two parts. The first characterizes the patient, with the hospitalization date, age, gender and dependence levels (Independent, partially dependent and fully dependent).* The second part describes the falls in terms of type (accidental, falls without physiological antecedents and with physiological antecedents and others $)^{\dagger}$, consequences (no consequences, mild, moderate, severe and death) ${ }^{\ddagger}$ and causes of falls, which is an open question in which the nurses describe the respective causes. Finally, in an open question, the nurses can describe the best strategy to prevent them.

The research project was submitted to the opinion of the Hospital's research ethics committee and received a favorable response.

\section{Results}

During the three years under analysis, 64 falls were registered, distributed as follows: 18 in 2007, 21 in 2008 and 25 in 2009. Patients who fell were mainly elderly (mean age 68 years) and partially dependent. According to Table 1 , however, falls were registered among patients of all dependence levels.

Table 1 - Distribution of falls according to patients' dependence level

\begin{tabular}{lccc}
\hline Dependence level & $\mathbf{2 0 0 7}$ & $\mathbf{2 0 0 8}$ & $\mathbf{2 0 0 9}$ \\
\hline Full & 3 & 3 & 10 \\
Partial & 9 & 11 & 15 \\
Independent & 6 & 7 & 0 \\
Total & 18 & 21 & 25 \\
\hline
\end{tabular}

As for the type of fall, in 2007, accidental falls were predominant, which are more related to extrinsic factors. In 2008 and 2009, on the other hand, falls with physiological antecedents were more frequent, which can be due to intrinsic factors. As shown in Table 2, the number of falls due to attempts to get up shows a continuing increase over the years. In 2008 and 2009, however, falls with physiological antecedents predominated, as causes were mostly due to intrinsic factors, namely confusion, agitation, decreased muscle strength, walking limitations and collapse, which are considered relevant aspects for fall risks ${ }^{(7)}$.

Table 2 - Description and comparison of falls causes in the hospital context in 2007-2009

\begin{tabular}{lccc}
\hline \multicolumn{1}{c}{ Falls causes } & $\mathbf{2 0 0 7}$ & $\mathbf{2 0 0 8}$ & $\mathbf{2 0 0 9}$ \\
\hline Attempt to get up & 4 & 9 & 15 \\
Confusion & 1 & 3 & 9 \\
Slipping/Slippery floor & 4 & 2 & 3 \\
Obstacle & 2 & 2 & 2 \\
Decreased muscle strength & 1 & 3 & 2 \\
Ineffective braking system & 3 & 1 & 2 \\
Walking limitations & 3 & 0 & 2 \\
Disequilibrium & 1 & 1 & 2 \\
Space-time disorientation & 0 & 1 & 1 \\
Mistaken perception of space in bed/ & 3 & 1 & 1 \\
Bunk bed & 0 & 3 & 0 \\
Collapse/ Dizziness & 0 & 1 & 0 \\
Dark & 3 & 1 & 4 \\
Headache/Agitation/Epileptic crisis & 0 & 1 & 0 \\
Hypoglycemia & 0 & 0 & 1 \\
Secondary effect of medication & 25 & 29 & 44 \\
Total & & & \\
\hline
\end{tabular}

Most of these falls are mild or not severe, take place in the patients' rooms and as a result of an attempt to get up. In 2007, however, one fall occurred with severe consequences and one death. Hence, regarding the consequences of falls, $40(63.5 \%)$ took place without consequences, $20(31.7 \%)$ with mild consequences, one $(1.6 \%)$ with moderate consequences, one $(1.6 \%)$ with severe consequences and one (1.6\%) death.

During the three years assessed, falls mostly took place in the room (53), followed by the corridor (6) and bathroom (5). Most events were registered during the morning shift (11:9:9 for each year, respectively), although a considerable number of events was found during the night shift $(2: 6: 12)$, followed by the afternoon shift with the lowest number of falls $(5: 6: 4)$.

\footnotetext{
*Independent - The person sees to his/her basic human needs alone in an acceptable way, so as to guarantee his/her homeostasis. Partially dependent - The person gets help from someone to accomplish actions needed to attend to his/her basic human needs or treatment, partially participating in these actions. Fully dependent - The person totally depends on someone to see to his/her basic human needs or apply treatment and cannot participate in these actions.

+Accidental - The person is oriented but suffers a fall inadvertently (e.g. fall from the bed, in the shower, while walking, stumbling, slipping, ...). Falls without physiological antecedents - The fall results from acute situations like: fainting, convulsive crisis, vascular accident, secondary effects and/or adverse reactions to drugs, (...). Falls with physiological antecedents - Intrinsic risk factors are identified, such as confusion, agitation, disorientation, walking limitation, ....ther. Which? Other kinds of falls, resulting from other risk factors.

¥No consequences - no damage/injuries whatsoever result for the patient. Mild - demand interventions like icepacks, steri-strip, injury antisepsis, $\mathrm{x}$-ray, ... without functional loss or disability. Moderate - result in sutures, manual fracture reduction, ...with temporary functional loss or temporary disability. Severe result in surgery, traction and permanent functional loss. Death.
} 


\section{Discussion}

Falls can compromise patients' healthy lifestyles and are considered one of the main causes of death in the elderly, which makes them an important Public Health problem $^{(1,3-4)}$.

One of the main findings in this study is the increased number of fall records over the years analyzed. As this study involved nurses from the unit, not only in data collection but also in systematic analysis, these results may seem to go against expectations. The increase in the number of fall records, however, may be related to the fact that, as the research advanced, the nurses got more sensitized and less defensive towards monitoring, perceiving that knowledge about the events and associated variables is fundamental for the adoption of preventive measures, to improve patients' safety. In fact, other studies have shown that the introduction of a patient safety culture in hospital care makes nurses acknowledge falls indicators as very pertinent for nursing care quality assessment ${ }^{(8)}$. Not only meetings held with the team contributed to this change, aimed at presenting and partially discussing the results, but also the fact that this concern is increasingly integrated in health services' quality policies. In fact, this increase in the number of records is particularly meaningful in the night shift, when only two nurses are present. What could be considered an easy form of identifying the professionals involved and, from a defensive perspective, what could lead to the hiding of these events, started to be analyzed as an indicator of the need for safe staff dimensioning and, thus, as an extremely important indicator of care quality and patient safety.

This reveals a change in the understanding of this phenomenon, from an act that is a priori considered as individual negligence to something that happens as a result of a set of factors that needed to be known and influenced. Reporting, analyzing and reorganizing procedures and environments are fundamental in a positive culture that permits enhancing nursing care quality and, thus, contributing to patient safety ${ }^{(9)}$.

Some resistance still remains, however, against the voluntary reporting of falls events, due to a past culture of punishment (through sanctions, disapproval of colleagues, loss of employment...), that is, due to the development of a blaming culture that still persists in some health institutions.

When we look at the shift during which the falls happened, the morning and night shifts appear as the main periods. More activities happen during the morning shifts, namely hygiene, getting up, rehabilitation, tests, among others, also coinciding with the period when patients themselves tend to take charge of their daily routines, whenever possible. These situations are prone to falls. On the other hand, in the afternoon and night shifts, although less activities are performed, the number of professionals at the service considerably drops, reducing the patients' frequent surveillance, besides the fact that the night period leads many patients to confusion and agitation. It should be mentioned that confusion is the second cause of falls in 2009. In a systematic literature review, the authors indicate that the study results vary with regard to falls in different shifts. The highest fall peak, however, coincides with the periods when the patients are most active, which vary from hospital to hospital(10)

The study shows that the mean age when falls occurred was between 64 and 75 years and, even when considering the age range of the hospitalized patients, this corroborates those people who call this problem a geriatric syndrome ${ }^{(3,7,11)}$.

Another important aspect to be taken into account is that most falls affected partially dependent patients. This groups manifests the greatest resistance to their new situation of dependence and thus try to manage their needs autonomously, increasing the risk of falls, namely through attempts to get up, which is the most prevalent cause of falls events. In elderly people with physical, psychological and social alterations, that is, with different dependence levels, falls prevention measures should be reinforced to guarantee a better quality of life, autonomy and independence(12). On the other hand, the fact that falls occur in independent patients should alert us to the relevance of extrinsic factors as facilitators of falls risks, which should be corrected to prevent them.

During the three years assessed, falls mainly took place in the room, followed by the corridor and bathroom. This situation may be due to the fact that patients were left unsupervised in the rooms for a longer time, as opposed to what happens in other places (corridor and bathroom). On the other hand, the room is where more obstacles exist (like the bedside table, chair, wheelchair, among others), limiting patients' mobility. This situation is in accordance with some studies that affirm that most falls occur in the room, namely when moving to the bed, armchair or wheelchair ${ }^{(5,10)}$ A smaller percentage of falls take place when walking from the bed to the bathroom, which also corroborates our study.

When joining the indicators: place, period, dependence level and cause of fall, wake-up times and 
the need to attend to basic needs in patients who consider themselves autonomous can be considered particularly sensitive for the occurrence of this event.

The fact that extrinsic factors decreased in comparison with subsequent years may be due to the team's efforts to correct some of the factors identified, like the review of braking systems in beds, wheelchairs, serum support with wheels, abolishment of floor wax and replacement by non-slip wax, purchasing of bars for all beds, placement of support rails in bathrooms, namely near toilets and in showers, placement of double stairs for patients to get into bed, as well as the request to purchase electric beds with articulated head- and footrests and incorporated protection bars that permit adjusting the bed height.

Based on these study results, we agree that the existence of a large number of falls risk factors emphasize the need for intentional prevention of this phenomenon, in response to the specific context of each units and its users ${ }^{(13)}$. Meetings between the researchers and nursing team to analyze the collected data showed to be an effective strategy to sensitize the nurses to record these incidents and to make further decisions on the introduction of preventive measures, such as the use of scales for risk assessment and for the systematic monitoring of events and their circumstances. As for the control of intervening factors, it is important to improve multidisciplinary work, as corrective measures at this level demand all team members' contributions. Annual service meetings with the multidisciplinary team were essential to propose new procedures, based on the results found, including the introduction of systematic falls risk assessment for all patients, applying the Downton scale during welcoming, as well as changes in the service dynamics.

\section{Conclusion}

This study demonstrated that falls are a phenomenon with multiple causes of great complexity, which makes the respective prevention difficult. Nevertheless, it seems important to highlight that both the present research results, including the process of their implementation, with the dissemination and discussion of results, have contributed to a broader understanding of this phenomenon and to the introduction of corrective measures aimed at enhancing patient safety. The findings indicate that research can be an important resource to modify nurses' behaviors and an added value in care orientation, thus contributing to increase quality.
The results found also indicate that this phenomenon should be permanently monitored and demands systematic assessment of the adopted measures' effects. The use of risk assessment scales and the design of contextually adequate guidelines will demand further research and training for all health professionals.

\section{References}

1. OMS - Who global report on falls prevention in older age. [Internet]. 2007. [acesso $27 \mathrm{fev} 2012$ ]; 1-47. Disponível em http://www.who.int/violence_injury_prevention/ other_injury/falls/en/.

2. Bukmans S, Vilela ALS, Pereira SRM, Lino VS, Santos. Quedas em Idosos: Prevenção. Sociedade Brasileira de Geriatria e Gerontologia - Projecto Directrizes da Associação Médica Brasileira e do Conselho Federal de Medicina. [Internet]. 2008 [acesso 27 fev 2012]; 1-10. Disponível em: http://www.projetodiretrizes.org.br/ projeto_diretrizes/082.pdf

3. Saraiva D. Quedas-indicador de qualidade assistencial. Nursing. 2008;18(235):28-35.

4. Serviço Nacional de Saúde. Tribuna medica press. [internet]. 2009 [acesso em: 3 Mar. 2010]. Disponível em: http://www.tribunamedicapress.pt/nacional-1/15429mais-de-quatro-mil-quedas

5. Diccini S, Pinho PG, Silva FO. Assessment of risk and incidence of falls in neurosurgical inpatients. Rev. LatinoAm.Enfermagem. 2008;16(4):752-7.

6. Castro Y. Aídas en los ancianos institucionalizados - valoración de riesgos e intervenciones. Rol Enferm. 2004;27(4):283-8.

7. Moreira M D, Costa A R, Felipe LR, Caldas CP. The association between nursing diagnoses and the occurrence of falls observed among elderly individuals assisted in an outpatient facility. Rev. Latino-Am. Enfermagem. 2007;15(2):311-7.

8. Almeida R, Abreu C; Mendes A. Quedas em doentes hospitalizados: contributos para uma prática baseada na prevenção. RevReferencia. 2010;3(2):163-72.

9. Abreu C. Perspectiva clínica de erro. SinaisVitais. 2009;83:38-41.

10. Evans D, Hodgkinson B, Lambert L, Wood J, Kowanko I. Falls in acute hospitals. A systematic review. South Australia: Joanna Briggs Institute for Evidence Based Nursing and Midwifwery; 1998.

11. Marin HF, Bourie P, Safran C. Desenvolvimento de um sistema de alerta para prevenção de quedas em pacientes hospitalizados. Rev. Latino-Am. Enfermagem. $2000 ; 8(3): 27-32$. 
12. Fabrício SCC, Rodrigues RAP, Junior MLC. Falls among older adults seen a São Paulo State public hospital: causes and consequences. Rev Saude Pública. 2004;38(1):93-9. 13. Gabriel CS, Melo MRAC, Rocha FLR, Bernardes A, Miguelaci T, Silva MLP. Utilização de indicadores de desempenho em serviço de enfermagem de hospital publico. Rev. Latino-Am. Enfermagem. 2011;19(5):1-9. 